Vol 1 No 12020 Juli 2020

Jurnal AlphaEuclidEdu

Received: 08/07/2020; Revised: 29/07/2020; Accepted: 30/07/2020

\title{
PENGGUNAAN THREE-TIER TEST UNTUK MENGUNGKAP HAMBATAN EPISTEMOLOGI DALAM MATERI SPLDV
}

\author{
${ }^{1}$ Yunita, Kurnia, ${ }^{2}$ Sugiatno, ${ }^{3}$ Suratman, Dede \\ ${ }^{1,2,3}$ Pascasarjana Pendidikan Matematika FKIP Universitas Tanjungpura Pontianak \\ kurniayunita04@gmail.com
}

\begin{abstract}
This research is aimed to describe the epistemology obstacle using the three-tier test in SMP Muhammadiyah 2 Pontianak. The method that used in this research is qualitative descriptive with the form of a survey. The subject is 33 students from grade 9 of SMP Muhammadiyah Pontianak academic year 2019/2020. The result from this research showed that the three-tier test instrument can reveal student's epistemology obstacles based on the indicator. Conceptual obstacle could reveal that students still lacking in constructing mathematics models. It happened because students still make mistakes in presupposing and confuse in reasoning. The procedural obstacle could reveal that incompatibility in question completion steps and the inability to complete the question in a very simple form. It happened because the student's working process is different from the direction in the question, students are not able to complete and do the questions. The technical operational obstacle could reveal that errors in calculating numbers from the sum of integers operation and errors in variable writing, writing incomplete steps and errors in switching the constants or the variables from previous steps.
\end{abstract}

Keywords: Three-tier Test, epistemology obstacle, SPLDV

\section{Pendahuluan}

Beberapa hasil penelitian mengungkapkan tentang hambatan belajar epistemologi dalam pembelajaran matematika, umumnya peneliti mengungkapnya dengan tes biasa (pilihan ganda tanpa alasan) dan tes pilihan ganda beralasan. Para peneliti yang mengungkap hambatan epistemologi menggunakan tes biasa diantaranya; Rasmania (2017) dan Yulfita (2017). Kemudian ada peneliti yang mengungkap hambatan epistemologi dengan menggunakan tes pilihan ganda beralasan, satu diantaranya; yaitu Yuliani (2016). Namun untuk tes biasa dan tes pilihan ganda beralasan yang digunakan oleh peneliti-peneliti terdahulu, belum mengkaji kepercayaan diri dari apa yang dijawab oleh siswa. Arslan, Cigdemoglu dan Moseley (2010) menyatakan bahwa jawaban bisa juga diidentifikasi sebagai tebakan beruntung atau rendahnya kepercayaan diri. Padahal, aspek keyakinan terhadap kemampuan diri siswa menempati posisi yang sangat penting dalam mendukung pencapaian tujuan pembelajaran matematika (Sugiman, 2009: 10). Untuk mengetahui tingkat kepercayaan siswa dalam menjawab soal, maka diperlukan suatu instrumen agar hasil pengukuran kepercayaan siswa dapat dilakukan dan dipertanggungjawabkan dengan baik. Satu diantara banyak instrumen untuk mengukur kepercayaan siswa adalah Three Tier Test.

Three-tier test adalah instrumen dengan tiga tingkatan: (1) content tier yang mengukur pengetahuan responden terkait suatu konsep/materi, (2) reason tier untuk melihat alasan dibalik jawaban yang diberikan oleh responden pada content tier dan (3) certainty respon index yang mengukur seberapa percaya diri responden akan jawabannya di tingkat pertama dan kedua (Arslan, Cigdemoglu dan Moseley, 2010). Untuk jawaban yang benar di tingkat satu dan dua yang disertai ketidakyakinan, menurut Arslan, Cigdemoglu dan Moseley (2010) bisa juga diidentifikasi sebagai tebakan beruntung atau rendahnya kepercayaan diri. Selain itu, penggunaannya sangat membantu untuk menilai pemahaman siswa karena bisa digunakan untuk sampel yang cukup banyak (Dindar dan Geban, 2011). Oleh sebab itu peneliti ingin menggunakan Three-tier test untuk mengungkap hambatan epistemologi siswa.

Menurut Brousseau (1997: 86) hambatan epistemologi adalah hambatan yang terjadi akibat keterbatasan siswa pada konteks baru siswa tampak kebingungan. Suryadi (2010: 11) menyatakan learning obstacle adalah satu di antara aspek yang perlu menjadi pertimbangan guru dalam mengembangkan antisipasi didaktik dan pendagogik. Hambatan epistemologi ini adalah salah satu hambatan belajar yang berasal dari siswa dan terdiri dari 3 indikator; (1) hambatan konseptual, (2) hambatan prosedural, dan (3) hambatan teknik operasional.

Satu diantara pembelajaran matematika kelas VIII yang diajarkan adalah materi SPLDV. Pada materi SPLDV ini diharapkan siswa dapat membuat model matematika berdasarkan permasalahan konstektual, menentukan penyelesaian persamaan linear dua variabel, dan menyelesaikan masalah dalam kehidupan sehari- 
Vol 1 No 12020 Juli 2020

Jurnal AlphaEuclidEdu

hari yang berkaitan dengan SPLDV. Namun kenyataannya banyak peserta didik yang masih kesulitan dalam mengerjakan soal SPLDV. Hal ini terlihat dari beberapa penelitian terdahulu diantaranya, Anis (2017) dan Dian (2015). Hasil penelitian menunjukkan bahwa masih kurangnya pemahaman konsep dalam mengidentifikasi suatu pernyataan, siswa mengalami kesulitan dalam memahami soal pada materi sistem persamaan linear dua variabel terletak pada metode penyelesaian SPLDV, siswa tidak dapat mengatur proses pengerjaan dengan baik, siswa kurang teliti dalam perhitungan, langkah-langkah terlalu panjang, dan salah dalam membuat model matematika.

Kenyataan di lapangan masih ada siswa yang mengalami hambatan saat mengerjakan soal materi SPLDV. Hal ini terlihat dari lembar jawaban siswa saat diberikan tugas yang diperoleh saat peneliti melakukan pra riset di SMP Mujahidin Pontianak pada tahun 2018/2019, terlihat bahwa siswa tidak menampilkan model matematika secara sistematis, ketidaksesuaian langkah penyelesaian soal dan kesalahan pada saat mencari nilai dari variabel $y$. Dari bukti-bukti tersebut mengindikasikan adanya suatu hambatan dari segi proses pengerjaan soal.

Dari kesalahan yang dilakukan siswa dan ketiga faktor hambatan belajar terlihat bahwa hambatan yang dialami siswa SMP Mujahidin Pontianak adalah hambatan yang berkaitan dengan hambatan epistemologi. Suryadi (2010: 14) mengungkapkan hambatan epistimologi adalah pengetahuan seseorang yang hanya terbatas pada konteks tertentu saja, sehingga pada saat dihadapkan di situasi yang berbeda bisa mengakibatkan pengetahuan yang dimilikinya menjadi tidak bisa digunakan atau mengalami kesulitan dalam menggunakannya. Berdasarkan uraian di atas, peneliti termotivasi ingin meneliti tentang hambatan belajar siswa khususnya untuk mengungkap hambatan epistemologi menggunakan three-tier test di SMP Muhammadiyah 2 Pontianak sebagaimana diangkat dalam judul "Penggunaan Three-tier Test Untuk Mengungkap Hambatan Epistemologi Dalam Materi SPLDV Di Sekolah Menengah Pertama”.

\section{Metode Penelitian}

Metode yang digunakan oleh peneliti dalam penelitian adalah deskriptif. Dalam penelitian ini Metode deskriptif merupakan prosedur pemecahan masalah dengan menggambarkan ataupun melukiskan keadaan subjek atau objek penelitian (seseorang, lembaga, masyarakat) pada saat sekarang berdasarkan fakta-fakta yang tampak, atau sebagaimana adanya (Nawawi, 2012: 67). Bentuk penelitian yang digunakan dalam penelitian ini adalah penelitian survei. Penelitian survei yang dilakukan adalah untuk mendapatkan fakta dari gejala-gejala yang ada dan mencari keterangan secara faktual tentang institusi sosial, ekonomi, dan politik dari suatu daerah atau suatu kelompok (Restu, 2010: 85). Subjek dalam penelitian ini adalah siswa kelas IX SMP Muhammadiyah 2 Pontianak tahun ajaran 2019/2020. Objek dalam penelitian ini adalah hambatan epistemologi menggunakan three-tier test pada materi SPLDV.

Prosedur penelitian adalah langkah-langkah yang digunakan dalam melakukan kegiatan penelitian di sekolah. Prosedur penelitian disusun dengan tujuan agar langkah-langkah penelitian lebih terarah pada permasalahan yang dikemukakan. Adapun langkah-langkah dalam penelitian ini adalah sebagai berikut:

\section{Tahap Persiapan Penelitian}

Pada tahap persiapan penelitian dilakukan beberapa kegiatan sebagai berikut: (1) Outline penelitian disetujui; (2) Menyusun desain penelitian; (3) Seminar desain penelitian; (4) Melakukan revisi terhadap desain penelitian berdasarkan hasil seminar yang telah dilakukan; (5) Menyusun instrumen penelitian berupa three tier test; (6) Melakukan validasi terhadap instrumen penelitian oleh dosen dan guru; (7) Melakukan revisi instrumen penelitian berdasarkan hasil validasi; (8) Mengadakan uji coba soal tes dalam bentuk three tier test di MTs Mathla'ul Anwar pada tanggal 13 November 2019; (9) Menganalisis data hasil uji coba instrumen; (10) Mengurus perizinan untuk melakukan penelitian di SMP Muhammadiyah 2 Pontianak; (11) Berkonsultasi dengan guru mata pelajaran matematika kelas IX SMP Muhammadiyah 2 Pontianak terkait waktu pelaksanaan dan subjek penelitian.

\section{Tahap Pelaksanaan Penelitian}

(1) Melakukan penelitian dengan memberikan soal three tier test kepada siswa kelas IX SMP Muhammadiyah 2 Pontianak pada tanggal 21 November 2019; (2) Mengoreksi hasil pekerjaan siswa dan menganalisis dengan teknik analisis data yang sesuai; (3) Melakukan wawancara kepada 6 siswa pada tanggal 22 November 2019; (4) Mengumpulkan data hasil analisis dari tes yang diberikan kepada siswa; (5) Mengklasifikasi dan menganalisis jawaban siswa untuk membedakan antara tidak mengalami hambatan dan mengalami hambatan; (6) Mendeskripsikan hambatan siswa berdasarkan hambatan epistemologi; (7) Melakukan perhitungan persentase terhadap hasil penelitian di tiap soal dan membuat rekapitulasi persentase rata- rata hambatan epistemologi; (8) Menganalisis letak hambatan siswa pada butir soal dengan persentase hambatan 
Vol 1 No 12020 Juli 2020

Jurnal AlphaEuclidEdu

epistemologi; (9) Menarik kesimpulan dari penelitian yang dilakukan Dengan menjawab rumusan masalah dalam penelitian berdasarkan hasil analisis data dan data temuan selama penelitian

\section{Tahap Akhir (Analisis Data)}

(1) Menyusun laporan hasil penelitian; (2) Mengkonsultasikan hasil penelitian kepada dosen pembimbing;

(3) Melaporkan hasil penelitian.

\section{Hasil Penelitian dan Pembahasan}

\subsection{Hasil Penelitian}

Instrumen pengumpulan data yang digunakan dalam penelitian ini berupa soal berbentuk Three-Tier Test dan wawancara. Soal Three-Tier Test yaitu soal yang berbentuk pilihan ganda dengan tiga tingkatan yang terdiri dari 10 soal. Wawancara dalam penelitian ini dilakukan kepada siswa yang diambil secara acak sebanyak enam orang dengan kategori yang paling banyak melakukan kesalahan dengan menanyakan mengenai jawabanjawaban yang dimiliki siswa yang menunjukkan terjadinya hambatan serta disesuaikan dengan pedoman wawancara. Hambatan didefinisikan menggunakan instrumen tes pilihan ganda dengan tiga tingkatan. Berikut rekapitulasi siswa yang mengalami hambatan.

Tabel 1. Rekapitulasi siswa yang mengalami hambatan

\begin{tabular}{lllllllllllllll}
\hline \multirow{2}{*}{ No } & \multicolumn{1}{c}{ Siswa } & \multicolumn{1}{c}{} & $\mathbf{1}$ & $\mathbf{2}$ & & $\mathbf{3}$ & $\mathbf{4}$ & $\mathbf{5}$ & $\mathbf{6}$ & $\mathbf{7}$ & $\mathbf{8}$ & $\mathbf{9}$ & $\mathbf{1 0}$ \\
\hline Mengalami Hambatan & 10 & 16 & 14 & 14 & 17 & 32 & 33 & 33 & 32 & 32 \\
\hline
\end{tabular}

Dari 33 siswa, yang mengalami hambatan sebanyak 33 siswa dan tidak ada siswa yang tidak mengalami hambatan. Dari 33 siswa yang mengalami hambatan paling banyak adalah nomor 7 dan 8 yaitu sebanyak 33 siswa. Berikut bentuk-bentuk hambatan yang dialami siswa

Tabel 2. Rekapitulasi Data Bentuk Hambatan

\begin{tabular}{|c|c|c|c|c|}
\hline \multirow{2}{*}{$\begin{array}{l}\text { Jumlah } \\
\text { Siswa }\end{array}$} & \multirow[b]{2}{*}{ No Soal } & \multicolumn{3}{|c|}{ Hambatan } \\
\hline & & Konseptual & Prosedural & Teknik Operasional \\
\hline \multirow{10}{*}{33} & 1 & 10 siswa $(30,3 \%)$ & & \\
\hline & 2 & 16 siswa $(48,49 \%)$ & & \\
\hline & 3 & 14 siswa $(43,75 \%)$ & & \\
\hline & 4 & 14 siswa $(43,75 \%)$ & & \\
\hline & 5 & 17 siswa $(51,5 \%)$ & & \\
\hline & 6 & 32 siswa $(96,96 \%)$ & 32 siswa $(96,96 \%)$ & 32 siswa $(96,96 \%)$ \\
\hline & 7 & 33 siswa $(100 \%)$ & 33 siswa $(100 \%)$ & 33 siswa $(100 \%)$ \\
\hline & 8 & 33 siswa $(100 \%)$ & 33 siswa $(100 \%)$ & 33 siswa $(100 \%)$ \\
\hline & 9 & 32 siswa $(96,96 \%)$ & 32 siswa $(96,96 \%)$ & 32 siswa $(96,96 \%)$ \\
\hline & 10 & 32 siswa $(96,96 \%)$ & 32 siswa $(96,96 \%)$ & 32 siswa $(96,96 \%)$ \\
\hline
\end{tabular}

Hambatan yang banyak terjadi yaitu pada soal nomor 7 dan 8 yaitu pada hambatan konseptual 100\%, hambatan prosedural $100 \%$ dan hambatan teknik operasional $100 \%$. Hambatan yang paling sedikit terjadi pada soal nomor 1 yaitu pada hambatan konseptual 30,3\%. Untuk mengetahui penyebab hambatan yang dimiliki siswa, peneliti melakukan wawancara kepada enam orang siswa yang diambil secara acak dan dianggap paling banyak mengalami hambatan. Penyebab hambatan yang dialami siswa bermacam- macam. Jenis wawancara yang dilakukan yaitu wawancara bebas (tak berstruktur). Menurut Kumar (2011:144) wawancara tidak terstruktur merupakan teknik wawancara yang bebas, karena peneliti tidak terikat dengan hal konten dan struktur sehingga peneliti tidak memerlukan pedoman wawancara yang sistematis. Penggalan wawancara dari soal nomor 1 sampai 10 yang telah dilakukan kepada enam siswa. 
Vol 1 No 12020 Juli 2020

Jurnal AlphaEuclidEdu

\subsection{Pembahasan}

\subsubsection{Hambatan Konseptual}

Soal pertama Terdapat 10 orang yang mengalami hambatan konseptual. Siswa tersebut dengan kode subyek MIB, MIA, ADH, CL, TR, FR, NW, Rds, Hrd, ANI. Dari 10 orang tersebut ada tiga alasan yang berbeda dan dapat dikatakan bahwa siswa mengalami hambatan, hambatan yang dialami siswa adalah hambatan konseptual karena siswa kurang mampu dan tepat dalam membuat model matematika.

Soal kedua Terdapat 16 orang yang mengalami hambatan konseptual. Siswa tersebut dengan kode subyek MIB, MIA, RSU, RP, ZPP, ADH, CL, MH, TR, RL, FR, NW, Rds, Hrd, ANI, MRF. Dari 16 orang tersebut ada empat alasan yang berbeda dan dapat dikatakan bahwa siswa mengalami hambatan, hambatan yang dialami siswa adalah hambatan konseptual karena siswa kurang mampu dan tepat dalam membuat model matematika.

Soal ketiga Terdapat 14 orang yang mengalami hambatan konseptual. Siswa tersebut dengan kode subyek MIB, MIA, ADH, CL, MH, TR, YI, RD, FR, NW, Rds, Hrd, ANI, MRF. Dari 14 orang tersebut ada empat alasan yang berbeda dan dapat dikatakan bahwa siswa mengalami hambatan, hambatan yang dialami siswa adalah hambatan konseptual karena siswa kurang mampu dan tepat dalam membuat model matematika.

Soal keempat Terdapat 14 orang yang mengalami hambatan konseptual. Siswa tersebut dengan kode subyek MIB, MIA, GP, ADH, CL, MH, TR, RD, FR, NW, Rds, Hrd, ANI, MRF. Dari 14 orang tersebut ada tiga alasan yang berbeda dan dapat dikatakan bahwa siswa mengalami hambatan, hambatan yang dialami siswa adalah hambatan konseptual karena siswa kurang mampu dan tepat dalam membuat model matematika.

Soal kelima Terdapat 17 orang yang mengalami hambatan konseptual. Siswa tersebut dengan kode subyek MIB, MIA, AAR, RSU, RP, ADH, CL, APH, MH, TR, RL, FR, NW, Rds, Hrd, ANI, MRF. Dari 17 orang tersebut ada tiga alasan yang berbeda dan dapat dikatakan bahwa siswa mengalami hambatan, hambatan yang dialami siswa adalah hambatan konseptual karena siswa kurang mampu dan tepat dalam membuat model matematika.

Soal keenam Terdapat 32 orang yang mengalami hambatan konseptual. Siswa tersebut dengan kode subyek MIB, RK, MHP, DPP, MIA, AAR, Rz, RSU, GP, RP, Az, ZPP, ADH, Rn CL, APH, MH, Rs, TR, RL, YI, Dn, AS, RD, MR, FR, MP, NW, Rds, Hrd, ANI, MRF. Dari 32 orang tersebut ada empat alasan yang berbeda dan dapat dikatakan bahwa siswa mengalami hambatan, hambatan yang dialami siswa adalah hambatan konseptual karena siswa kurang mampu dan tepat dalam membuat model matematika.

Soal ketujuh Terdapat 33 orang yang mengalami hambatan konseptual. Siswa tersebut dengan kode subyek MIB, RK, MHP, DPP, MIA, AAR, Rz, RSU, GP, RP, Az, ZPP, ADH, Rn CL, APH, MH, Rs, TR, RL, YI, Dn, AS, RD, MR, FR, MP, NW, Rds, Hrd, MIm, ANI, MRF. Dari 33 orang tersebut ada empat alasan yang berbeda dan dapat dikatakan bahwa siswa mengalami hambatan, hambatan yang dialami siswa adalah hambatan konseptual karena siswa kurang mampu dan tepat dalam membuat model matematika.

Soal kedelapan Terdapat 33 orang yang mengalami hambatan konseptual. Siswa tersebut dengan kode subyek MIB, RK, MHP, DPP, MIA, AAR, Rz, RSU, GP, RP, Az, ZPP, ADH, Rn CL, APH, MH, Rs, TR, RL, YI, Dn, AS, RD, MR, FR, MP, NW, Rds, Hrd, MIm, ANI, MRF. Dari 33 orang tersebut ada empat alasan yang berbeda dan dapat dikatakan bahwa siswa mengalami hambatan, hambatan yang dialami siswa adalah hambatan konseptual karena siswa kurang mampu dan tepat dalam membuat model matematika.

Soal kesembilan Terdapat 32 orang yang mengalami hambatan konseptual. Siswa tersebut dengan kode subyek MIB, RK, MHP, DPP, MIA, AAR, Rz, RSU, GP, RP, Az, ZPP, ADH, Rn CL, APH, MH, Rs, TR, RL, YI, Dn, AS, RD, MR, FR, MP, NW, Rds, Hrd, ANI, MRF. Dari 32 orang tersebut ada lima alasan yang berbeda dan dapat dikatakan bahwa siswa mengalami hambatan, hambatan yang dialami siswa adalah hambatan konseptual karena siswa kurang mampu dan tepat dalam membuat model matematika.

Soal kesepuluh Terdapat 32 orang yang mengalami hambatan konseptual. Siswa tersebut dengan kode subyek MIB, RK, MHP, MIA, AAR, Rz, RSU, GP, RP, Az, ZPP, ADH, Rn CL, APH, MH, Rs, TR, RL, YI, Dn, AS, RD, MR, FR, MP, NW, Rds, Hrd, MIm, ANI, MRF. Dari 32 orang tersebut ada empat alasan yang berbeda dan dapat dikatakan bahwa siswa mengalami hambatan konseptual karena siswa kurang mampu dan tepat dalam membuat model matematika.

Dari 10 soal yang paling banyak mengalami hambatan konseptual pada nomor 7 dan 8 yaitu 33 orang (100\%), dan yang paling sedikit mengalami hambatan konseptual pada nomor 1 yaitu 10 orang (30,3\%). Dari 10 soal tersebut pada soal pertama, keempat dan kelima terdapat 3 jawaban yang berbeda, pada soal kedua, ketiga, keenam, ketujuh, kedelapan dan kesepuluh terdapat empat jawaban yang berbeda, pada soal kesembilan terdapat 5 jawaban yang berbeda.

\subsubsection{Hambatan Prosedural}

Soal keenam Terdapat 32 orang yang mengalami hambatan. Siswa tersebut dengan kode subyek MIB, RK, MHP, DPP, MIA, AAR, Rz, RSU, GP, RP, Az, ZPP, ADH, Rn CL, APH, MH, Rs, TR, RL, YI, Dn, AS, RD, 
Vol 1 No 12020 Juli 2020

Jurnal AlphaEuclidEdu

MR, FR, MP, NW, Rds, Hrd, ANI, MRF. Dari 32 orang tersebut ada empat alasan yang berbeda dan dapat dikatakan bahwa siswa mengalami hambatan, hambatan yang dialami siswa adalah hambatan prosedural karena dalam proses perhitungan soal yang diperintahkan berbeda dengan proses perhitungan yang telah dilakukan siswa dan siswa kurang mampu menyelesaikan soal hingga bentuk paling akhir.

Soal ketujuh Terdapat 33 orang yang mengalami hambatan. Siswa tersebut dengan kode subyek MIB, RK, MHP, DPP, MIA, AAR, Rz, RSU, GP, RP, Az, ZPP, ADH, Rn CL, APH, MH, Rs, TR, RL, YI, Dn, AS, RD, MR, FR, MP, NW, Rds, Hrd, MIm, ANI, MRF. Dari 33 orang tersebut ada empat alasan yang berbeda dan dapat dikatakan bahwa siswa mengalami hambatan, hambatan yang dialami siswa adalah hambatan prosedural karena dalam proses perhitungan soal yang diperintahkan berbeda dengan proses perhitungan yang telah dilakukan siswa dan siswa kurang mampu menyelesaikan soal hingga bentuk paling akhir.

Soal kedelapan Terdapat 33 orang yang mengalami hambatan. Siswa tersebut dengan kode subyek MIB, RK, MHP, DPP, MIA, AAR, Rz, RSU, GP, RP, Az, ZPP, ADH, Rn CL, APH, MH, Rs, TR, RL, YI, Dn, AS, RD, MR, FR, MP, NW, Rds, Hrd, MIm, ANI, MRF. Dari 33 orang tersebut ada empat alasan yang berbeda dan dapat dikatakan bahwa siswa mengalami hambatan, hambatan yang dialami siswa adalah hambatan prosedural karena dalam proses perhitungan soal yang diperintahkan berbeda dengan proses perhitungan yang telah dilakukan siswa dan siswa kurang mampu menyelesaikan soal hingga bentuk paling akhir.

Soal kesembilan Terdapat 32 orang yang mengalami hambatan. Siswa tersebut dengan kode subyek MIB, RK, MHP, DPP, MIA, AAR, Rz, RSU, GP, RP, Az, ZPP, ADH, Rn CL, APH, MH, Rs, TR, RL, YI, Dn, AS, RD, MR, FR, MP, NW, Rds, Hrd, ANI, MRF. Dari 32 orang tersebut ada lima alasan yang berbeda dan dapat dikatakan bahwa siswa mengalami hambatan, hambatan yang dialami siswa adalah hambatan prosedural karena karena dalam proses perhitungan soal yang diperintahkan berbeda dengan proses perhitungan yang telah dilakukan siswa dan siswa kurang mampu menyelesaikan soal hingga bentuk paling akhir.

Soal kesepuluh Terdapat 32 orang yang mengalami hambatan. Siswa tersebut dengan kode subyek MIB, RK, MHP, MIA, AAR, Rz, RSU, GP, RP, Az, ZPP, ADH, Rn CL, APH, MH, Rs, TR, RL, YI, Dn, AS, RD, MR, FR, MP, NW, Rds, Hrd, MIm, ANI, MRF. Dari 32 orang tersebut ada empat alasan yang berbeda dan dapat dikatakan bahwa siswa mengalami hambatan, hambatan yang dialami siswa adalah hambatan prosedural karena dalam proses perhitungan soal yang diperintahkan berbeda dengan proses perhitungan yang telah dilakukan siswa dan siswa kurang mampu menyelesaikan soal hingga bentuk paling akhir.

Dari 5 soal ada 2 soal yang semua siswa tidak bisa menjawab dengan prosedur yang tepat dan 3 soal nya ada 1 orang siswa yang bisa tetapi 32 orang siswa tidak bisa menjawab dengan prosedur yang tepat. Persentase hambatan prosedural pada nomor 7 dan 8 yaitu 33 orang (100\%), dan persentase hambatan prosedural pada nomor 6, 9 dan 10 yaitu 32 orang $(96,96 \%)$. Dari 5 soal tersebut pada soal keenam, ketujuh, kedelapan dan kesepuluh terdapat empat jawaban yang berbeda, pada soal kesembilan terdapat 5 jawaban yang berbeda.

\subsubsection{Hambatan Teknik Operasional}

Soal keenam Terdapat 32 orang yang mengalami hambatan. Siswa tersebut dengan kode subyek MIB, RK, MHP, DPP, MIA, AAR, Rz, RSU, GP, RP, Az, ZPP, ADH, Rn CL, APH, MH, Rs, TR, RL, YI, Dn, AS, RD, MR, FR, MP, NW, Rds, Hrd, ANI, MRF. Dari 32 orang tersebut ada empat alasan yang berbeda dan dapat dikatakan bahwa siswa mengalami hambatan, hambatan yang dialami siswa adalah hambatan teknik operasional yaitu siswa kurang mampu untuk menghitung nilai dari operasi hitung dan siswa kurang mampu untuk menuliskan simbol matematikanya, dan pada jawaban ada nilai konstanta atau nilai variabel yang terlewat maupun kesalahan memindahkan konstanta atau variabel dari setiap langkah.

Soal ketujuh Terdapat 33 orang yang mengalami hambatan. Siswa tersebut dengan kode subyek MIB, RK, MHP, DPP, MIA, AAR, Rz, RSU, GP, RP, Az, ZPP, ADH, Rn CL, APH, MH, Rs, TR, RL, YI, Dn, AS, RD, MR, FR, MP, NW, Rds, Hrd, MIm, ANI, MRF. Dari 33 orang tersebut ada empat alasan yang berbeda dan dapat dikatakan bahwa siswa mengalami hambatan, hambatan yang dialami siswa adalah hambatan teknik operasional yaitu siswa kurang mampu untuk menghitung nilai dari operasi hitung dan siswa kurang mampu untuk menuliskan simbol matematikanya, dan pada jawaban ada nilai konstanta atau nilai variabel yang terlewat maupun kesalahan memindahkan konstanta atau variabel dari setiap langkah.

Soal kedelapan Terdapat 33 orang yang mengalami hambatan. Siswa tersebut dengan kode subyek MIB, RK, MHP, DPP, MIA, AAR, Rz, RSU, GP, RP, Az, ZPP, ADH, Rn CL, APH, MH, Rs, TR, RL, YI, Dn, AS, RD, MR, FR, MP, NW, Rds, Hrd, MIm, ANI, MRF. Dari 33 orang tersebut ada empat alasan yang berbeda dan dapat dikatakan bahwa siswa mengalami hambatan, hambatan yang dialami siswa adalah hambatan teknik operasional yaitu siswa kurang mampu untuk menghitung nilai dari operasi hitung dan siswa kurang mampu untuk menuliskan simbol matematikanya, dan pada jawaban ada nilai konstanta atau nilai variabel yang terlewat maupun kesalahan memindahkan konstanta atau variabel dari setiap langkah.

Soal kesembilan Terdapat 32 orang yang mengalami hambatan. Siswa tersebut dengan kode subyek MIB, RK, MHP, DPP, MIA, AAR, Rz, RSU, GP, RP, Az, ZPP, ADH, Rn CL, APH, MH, Rs, TR, RL, YI, Dn, AS, 
Vol 1 No 12020 Juli 2020

Jurnal AlphaEuclidEdu

RD, MR, FR, MP, NW, Rds, Hrd, ANI, MRF. Dari 32 orang tersebut ada lima alasan yang berbeda dan dapat dikatakan bahwa siswa mengalami hambatan, hambatan yang dialami siswa adalah hambatan teknik operasional yaitu siswa kurang mampu untuk menghitung nilai dari operasi hitung dan siswa kurang mampu untuk menuliskan simbol matematikanya, dan pada jawaban ada nilai konstanta atau nilai variabel yang terlewat maupun kesalahan memindahkan konstanta atau variabel dari setiap langkah.

Soal kesepuluh Terdapat 32 orang yang mengalami hambatan. Siswa tersebut dengan kode subyek MIB, RK, MHP, MIA, AAR, Rz, RSU, GP, RP, Az, ZPP, ADH, Rn CL, APH, MH, Rs, TR, RL, YI, Dn, AS, RD, MR, FR, MP, NW, Rds, Hrd, MIm, ANI, MRF. Dari 32 orang tersebut ada empat alasan yang berbeda dan dapat dikatakan bahwa siswa mengalami hambatan, hambatan yang dialami siswa adalah hambatan teknik operasional yaitu siswa kurang mampu untuk menghitung nilai dari operasi hitung dan siswa kurang mampu untuk menuliskan simbol matematikanya, dan pada jawaban ada nilai konstanta atau nilai variabel yang terlewat maupun kesalahan memindahkan konstanta atau variabel dari setiap langkah.

Dari 5 soal ada 2 soal yang semua siswa tidak bisa menjawab dengan teknik operasional yang tepat dan 3 soal nya ada 1 orang siswa yang bisa tetapi 32 orang siswa tidak bisa menjawab dengan teknik operasional yang tepat. Persentase hambatan teknik operasional pada nomor 7 dan 8 yaitu 33 orang (100\%), dan persentase hambatan teknik operasional pada nomor 6, 9 dan 10 yaitu 32 orang $(96,96 \%)$. Dari 5 soal tersebut pada soal keenam, ketujuh, kedelapan dan kesepuluh terdapat empat jawaban yang berbeda, pada soal kesembilan terdapat 5 jawaban yang berbeda.

\section{Kesimpulan}

Dari hasil penelitian dan pembahasan maka dapat disimpulkan:

Berdasarkan deskripsi data hambatan epistemologi siswa pada materi SPLDV di kelas IX SMP Muhammadiyah 2 Pontianak telah diberikan 10 soal dalam bentuk Three-tier Test dan diperjelas dengan wawancara dengan tiga indicator yaitu; (1) hambatan konseptual, (2) hambatan procedural, dan (3) hambatan teknik operasional. Secara umum hambatan epistemologi pada materi SPLDV di kelas IX SMP Muhammadiyah 2 Pontianak masih tinggi. Untuk memperjelas kesimpulan sebagai berikut:

1. Hambatan konseptual yang dialami siswa kelas IX SMP Muhammadiyah 2 Pontianak adalah hambatan dalam membuat model matematika. Hal ini, terjadi karena siswa salah dalam memisalkan, siswa masih bingung memberikan alasan, dan siswa tidak tau menjawab alasannya.

2. Hambatan prosedural yang dialami siswa kelas IX SMP Muhammadiyah 2 Pontianak adalah hambatan dalam ketidaksesuain langkah penyelesaian soal dan belum mampu menyelesaikan soal sampai pada bentuk paling sederhana. Hal ini, terjadi karena siswa menyelesaikan soal menggunakan metode yang tidak sesuai dengan perintah soal, siswa tidak menyelesaikan hingga akhir, siswa belum mampu menyelesaikan soal, siswa hanya membuat model matematika, dan siswa mampu memberikan jawaban namun tidak disertai dengan cara

3. Hambatan teknik operasional yang dialami siswa kelas IX SMP Muhammadiyah 2 Pontianak adalah kesalahan menghitung nilai dari suatu operasi penjumlahan bilangan bulat dan kesalahan dalam penulisan seperti salah menuliskan variabel, tidak menuliskan langkah dengan lengkap, dan salah dalam memindahkan konstanta atau variabel dari langkah sebelumnya.

\section{Referensi}

Anis. 2017. Analisis Kesulitan Siswa Dalam Memahami Materi Sistem Persamaan Linear Dua Variabel Pada Kelas Viii G Di Mts Ma'arif Bakung Udanawu Blitar Tahun Ajaran 2016/2017. Skripsi.Tulungagung: Institut Agama Islam Negeri.

Arslan, H. O., Cigdemoglu, C., \& Moseley, C. 2010. A Three-Tier Diagnostic Test To Assess Pre-Service Teachers Misconception About Global Warming, Greenhouse Effect, Ozone Layer Depletion and Acid Rain. International Journal of science Education. 34(11): 1667-1686.

Brousseau, G. (1997). Theory Of Didactical Situations In Mathematics. Dordrecht: Kluwer Academic Publishers.

Dian. 2015. Analisis kesulitan siswa dalam memecahkan masalah matematika materi sistem persamaan linear dua variabel pada siswa kelas VIII semester ganjil Sekolah Menengah Pertama Muhammadiyah 4 Sambi Tahun ajaran 2015/2016. Skripsi.Surakarta: Universitas Muhammadiyah

Nawawi, Hadari. 2012. Metode Penelitian di Bidang Sosial, Yogyakarta: Gajah Mada University Press

Suryadi, Didi. (2010). Didactical Design Research (DDR) Dalam Pengembangan Pembelajaran Matematika 1, Jurnal Ilmu Pendidikan. 